Chirurgia (2019) 114: 541-549

No. 5, September - October

Copyright@ Celsius

http://dx.doi.org/10.21614/chirurgia.114.5.541

\title{
The Value of Imaging of the Parathyroid Glands in Secondary Hyperparathyroidism
}

\author{
Victor Strambu', Mircea Bratucu', Dragos Garofil', Costin Pasnicu', Vlad Paic², Mihai Zurzu², Anca Tigora², \\ Florian Popa', Petru Radu'
}

'Surgery Department, "Carol Davila" Clinical Nephrology Hospital, Department 10 U.M.F. "Carol Davila" Bucharest, Romania 2"Carol Davila" Clinical Nephrology Hospital Bucharest, Romania

Corresponding author:

Mircea Nicolae Bratucu, MD

Surorilor Street, no. 31, sector 1

Bucharest, Romania

E-mail: bratucu_mircea@yahoo.com

\section{Abbreviations:}

SHPT - Secondary Hyperparathyroidism; CKD - Chronic Kidney Disease:

CT - Computer Tomographic;

MRI - Nuclear Magnetic Resonance;

PET - Positron Emission Tomography.

\section{Rezumat}

Valoarea imagisticii glandelor paratiroide în hiperparatiroidismul secundar

Este estimat că un procent important, de până la 90\%, din pacienții cu insuficiența renală cronică dezvoltă hiperparatiroidism secundar (HPS). Cu toate că boala prezintă multiple manifestări, cea mai importantă caracteristică patologică, din punctul de vedere al mortalității crescute, e reprezentată de calcificările ectopice arteriale, miocardice şi valvulare cardiace. Acestea sunt progresive şi conduc la hipertensiune arterială, hipertrofie ventriculară stângă, blocuri atrio-ventriculare, angină pectorală şi infarct miocardic. Aşadar riscul evenimentelor cardio-vasculare este mult crescut. Eşecul terapiei medicamentoase în a stăpâni progresia bolii reprezintă o indicație pentru paratiroidectomie. In HPS sunt afectate toate glandele paratiroide, de aici necesitatea de a decela intraoperator 4 glande, prin explorare cervicală bilaterală. Totuşi, având în vedere posibilitatea unor localizări ectopice a acestor glande cât şi eventualitatea unora supranumerare, este de dorit a avea preoperator o hartă imagistică cât mai exactă, evitând astfel riscul recurenței postoperatorii. Investigațiile imagistice disponibile sunt reprezentate de ecografia regiunii cervicale, scintigrafia paratiroidiană şi de cele de linia a doua - examinare CT sau RMN. Dacă în hiperparatiroidismul primar, unde există un singur adenom paratiroidian (sau două), rezultatele imagistice preoperatorii sunt satisfăcătoare, în HPS există destule cazuri în care imagistica nu evidențiază toate cele patru glande paratiroide.

Cuvinte cheie: paratiroide, hiperparatiroidism secundar, insuficiența renală cronică, scintigrafie
Received: 02.09.2019

Accepted: 09.10.2019 


\begin{abstract}
It is estimated that up to $90 \%$ of patients with chronic kidney disease develop secondary hyperparathyroidism (sHPT). Although the disease has multiple manifestations, the most important pathological feature, from the point of view of increased mortality, is represented by the ectopic arterial, myocardial and cardiac valvular calcifications. The calcifications are progressive and lead to high blood pressure, left ventricular hypertrophy, atrio-ventricular blocks, angina and myocardial infarction. Therefore the risk of cardio-vascular events is increased. Failure of drug therapy to control disease progression is an indication for parathyroidectomy. In sHPT all parathyroid glands are affected, hence the need to detect 4 glands intraoperatively, by bilateral cervical exploration. However, considering the possibility of ectopic localization of these glands as well as the possibility of some supernumerary glands, it is desirable to have an imagistic map as accurate as possible, thus avoiding the risk of postoperative recurrence. The available imaging investigations are represented by the ultrasound of the cervical region, the parathyroid scintigraphy and those of the second line CT or MRI examination. If in primary hyperparathyroidism, where there is only one parathyroid adenoma (or two), the preoperative imaging results are satisfactory, in sHPT there are many cases in which the imaging does not reveal all four parathyroid glands.
\end{abstract}

Key words: parathyroids, secondary hyperparathyroidism, chronic kidney disease, scintigraphy

\section{Introduction}

The clinical presentation of secondary hyperparathyroidism is that of a patient with chronic kidney disease (CKD), fragile, exhausted by suffering and prolonged treatment on which overlap significant comorbidities such as anemia, high blood pressure, ischemic heart disease, viral hepatitis, diabetes mellitus, immune deficits occur. Mortality in these patients is 6-7.8 times higher than that of the general population (1). In these patients, secondary hyperparathyroidism (sHPT) only enhances the distress whose underlying lesions consist of bone demineralizations, vascular, valvular heart calcifications at the level of the soft tissues as well.

From all the above mentioned, it is clear that these patients live in a continuous suffering. Up to a certain point, the drug treatment is able to slow the progression of the disease. But when it fails, the patient must undergo parathyroidectomy - in fact the curative treatment of sHPT.

Currently, three surgical techniques are described and accepted, each with its supporters and opponents. Whether total parathyroidectomy, subtotal parathyroidectomy or total parathyroidectomy with immediate autotransplantation are performed, each patient undergoes preoperative imaging investigations. The aim is to obtain an exact preoperative map of the locations of the parathyroid glands. The possible ectopic gland locations as well as the eventuality of supernumerary glands require it. Not in a few cases though, preoperative imaging is not able to detect all parathyroid glands. If neither intraoperative exploration does not reveal all of them, the danger of recurrence of the disease is present and will require surgical reintervention, which is undesirable in these extremely ill patients.

\section{Variants of Position and Number of Parathyroid Glands}

Although the general rule is that there are 4 parathyroid glands and are located in the thyroid lodge, posterior to the thyroid gland, there are a number of position abnormalities. At the same time, the number of parathyroid glands is also subject to variability. Thus, there are patients who have supernumerary glands. The percentages in the specialty literature regarding the existence of additional glands vary within quite large limits - 5-13\% and even more. Table 1 presents the results of several authors regarding the percentage of supernumerary parathyroid glands (Table 1). Although these 
Table 1. Various studies on the percentage of supernumerary parathyroid glands

\begin{tabular}{llc}
\hline Author/year & Number of cases included in the study & Supernumerary glands \\
\hline Gilmour 1938 (2) & 428 necropsies & $6.5 \%$ \\
\hline Wang 1976 (3) & 160 necropsies & $2.5 \%$ \\
\hline Akerstrqm 1984 (4) & 503 necropsies & $13 \%$ \\
\hline Hooghe $1992(5)$ & 416 paratyroidectomies & $5 \%$ \\
\hline
\end{tabular}

are mostly studies based on autopsy examinations, the large number of subjects in the group is relevant. In our experience, in more than 400 parathyroidectomies performed so far, we have encountered only 3 cases of supernumerary glands documented anatomopathologically. Therefore, although their actual frequency is difficult to assess, they should be considered as a source of PTH hypersecretion and disease recurrence.

Regarding the position abnormalities of the parathyroid glands, their variability is even greater. Due to embryonic development, the inferior parathyroid glands are more susceptible to ectopic localization. Hooghe, at 416 parathyroidectomies, detects $19 \%$ of ectopic glands (5).

McIntyre shows in 309 parathyroidectomies 6\% intrathyroid glands (6). Libutti describes, analyzing 269 patients, $7 \%$ intrathyroidal parathyroid glands (7). Analyzing 54 cases with ectopic parathyroid glands, Shen highlights the following locations: paraesophageal 28\%, intratymic $24 \%$, mediastinal $26 \%$, intratyroidal $11 \%$, in the carotid artery sheath $9 \%$, in cervical position 2\% (8). Wang describes, out of 312 inferior parathyroids, 6 mediastinal ectopic $(2 \%)$ glands (3). Analyzing a lot of 60 patients with sHPT, Butterworth describes $2 \%$ ectopias of superior parathyroid glands and $11 \%$ of inferior parathyroids glands (9).

From all the above mentioned, it clearly comes out the variability of the percentages presented by various authors as well as the possibility of a wide distribution of these glands, cranially from the angle of the mandible, and caudally to the mediastinum. As far as we are concerned, we have encountered several cases with ectopic locations, few in number but certain source of surgical reintervention (3.5\% of the first 200 parathyroidectomies performed) (10).

\section{Imaging of Parathyroid Glands}

Preoperative imaging of all parathyroid glands is a request that unfortunately cannot always be achieved in patients with sHPT. The noninvasive imaging arsenal of these patients includes the ultrasound examination of the cervical region, parathyroid scintigraphy, computer-tomographic (CT) examination and nuclear magnetic resonance (MRI). Compared to primary hyperparathyroidism, where there is an increase in the volume of a single parathyroid gland (rarely two), the difficulty in sHPT is to detect all the parathyroid glands. Most often the appearance of hyperplasia in sHPT is not uniform. This results in the coexistence, in the same patient, of increased parathyroids of unequal volume (Fig. 1), which can lead to the inability to identify the small size glands.

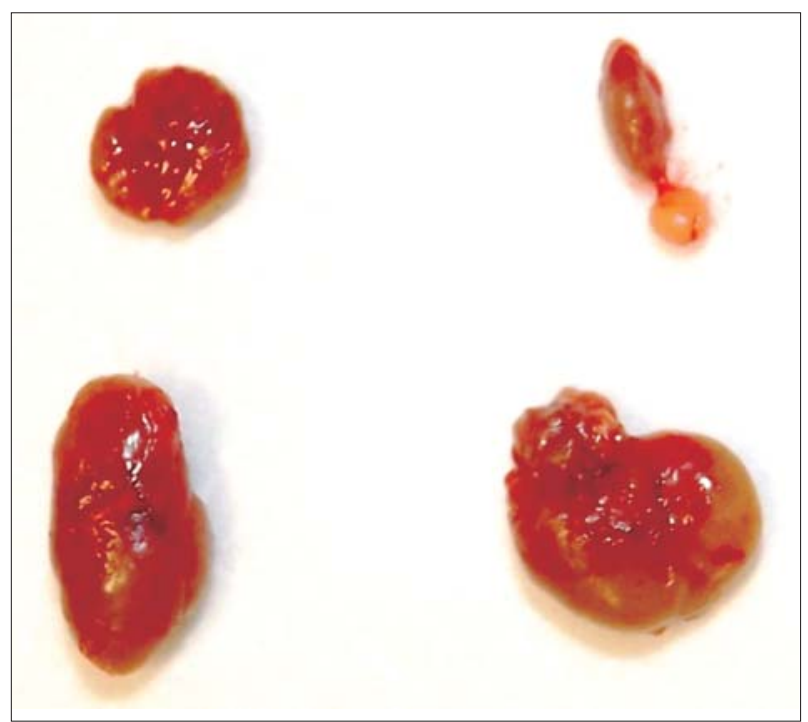

Figure 1. SHTP excision specimens: coexistence of parathyroids with unequal volumes (Clinical archive) 


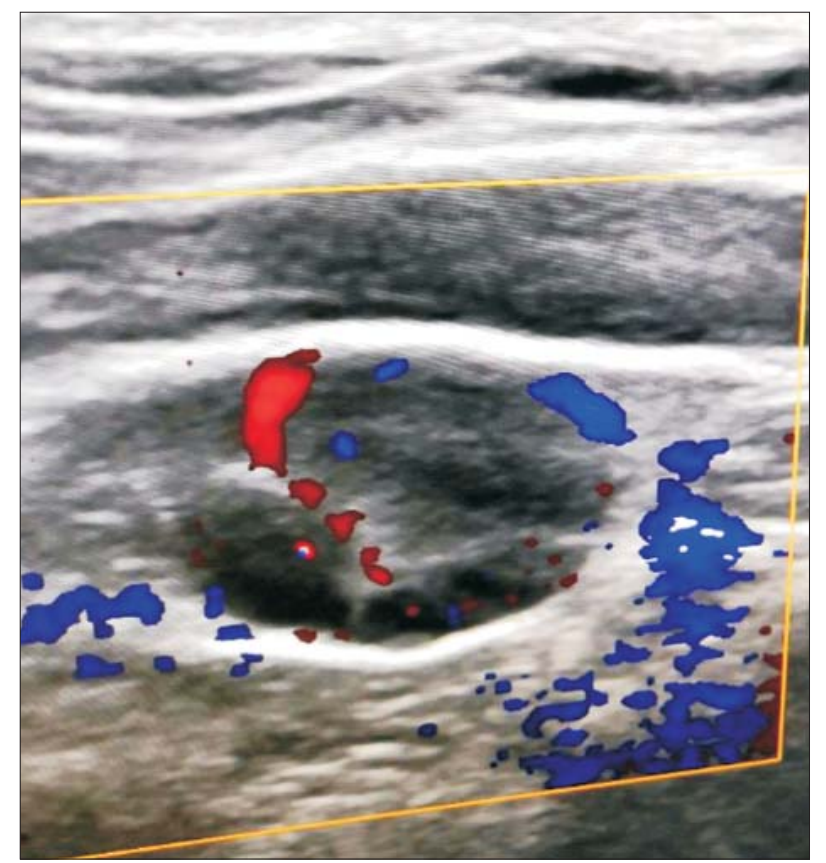

Figure 2. Ultrasound image of a parathyroid gland in SHTP (Clinical Archives)

The most used imaging investigation is the ultrasound of the anterior cervical region. Using a high frequency linear transducer (over 7.5 Mhz), the method is not usually able to detect normal parathyroid glands. The investigation has a sensitivity that varies within quite large limits - 36-76\% (11) - and is dependent on the examiner's experience. The appearance is of an oval or asymmetrical hypoecogenic mass, having variable dimensions, separated by the thyroid gland (Fig. 2). It may rarely present with calcifications or cystic degeneration. Doppler examination may be able to reveal the parathyroid vascular pedicle and a vascular arch located at the periphery of the gland $(12,13)$. At the same time, the ultrasound offers relationships regarding the morphology of the thyroid gland, an important aspect considering that not in a few cases the parathyroid and thyroid pathologies coexist. Differentiating between a parathyroid gland and a posterior thyroid nodule can sometimes be difficult, the examiner's experience having the last word in these cases.

Unfortunately, ultrasonography is limited in the discovery of ectopic parathyroids, which can be "hidden" retrosternal or retroclavicular, thus being masked acoustically. At the same time, parathyroids placed retrotracheal or retroesophageal may not be observed due to the tracheal air that blocks the signal $(13,14)$. Of course, the imaging sensitivity can be increased by associating the ultrasound with the parathyroid scintigraphy. In most cases ultrasonography detects 2 or 3 parathyroid glands. Pulgar, following 71 patients (of which 58 with sHPT and 13 with tertiary hyperparathyroidism), describes pathological changes of parathyroids in 38 of the cases $(53.5 \%)$ of which only in 9 cases the hyperplasia of all 4 parathyroids was present (15). Another study revealed by ultrasound only 139 hyperplastic parathyroids in 47 patients with sHTP - between 2 and 4 glands in each case (16).

However, with all its limitations, we believe that the ultrasound of the cervical region should be performed in all cases of sHTP. Being noninvasive and having a low cost, it should become a routine. In the event of post-operative recurrence of the disease, ultrasonography must be associated with a more sensitive imaging examination.

\section{Parathyroid Scintigraphy}

This investigation, compared with the one presented above, has the advantage of a functional exploration. It is based on the capture of a radiotracer by the hyperfunctional parathyroids, the normal glands remaining unseen. Although there are currently several methods to perform scintigraphy, the most used remains Technetiu99m-sestamibi (99mTc-sestamibi) $(17,18,19)$. Unfortunately, $99 \mathrm{mTc}$-sestamibi is also captured by the thyroid gland, not being specific for hyperplastic parathyroid tissue. It is important for the examination to cover both the cervical region and the mediastinum to reveal any ectopic glands $(20,21)$. Two different scintigraphic techniques are accepted, to compensate for the lack of specificity of the $99 \mathrm{mTc}$-sestamibi, namely that of the double-phase with a singletracer (dual-phase) and that of the double-tracer with subtraction (dual-isothope) (22).

The single tracer method is based on the different half-times of the tracer at the level of the thyroid and parathyroid glands, scanning the cervical region in two stages, in an early phase at 10-30 minutes and a late phase at 90- 
180 minutes (22). Finally, there is an increased uptake of the tracer at the level of the adenomatous parathyroid. Unfortunately, the sensitivity is high in the adenomas of primary hyperparathyroidism, decreasing in the pluriglandular disease of sHTP.

The alternative to the method described above is represented by the double tracer and subtraction technique that uses both $99 \mathrm{mTc}^{-}$ sestamibi and a second thyroid tissue specific tracer. The second tracer may be Technetium$99 \mathrm{~m}$-pertechnet or $123 \mathrm{I}$, both showing only thyroid uptake (18). The acquisition of the images for each radio transmitter is performed, and then the subtraction is computerized; "the image" of the thyroid gland is diminished, thus highlighting only the capture in the parathyroid glands $(18,20)$. Although some authors consider the sensitivity of the double-tracer method higher than that the single-tracer technique (23), in sHTP multiglandular hyperplasia the results were not as expected (18). There are other opinions that have not reached a consensus regarding the superiority of one of the two methods (19,21). In the "Carol Davila" Clinical Hospital of Nephrology, scintigraphy with a single tracer is used, having a state-of-the-art apparatus. Prior to examination, the patient must meet several conditions: to discontinue the treatment with thyroid hormones (at least 10 days prior to examination), with antihypertensive beta-blockers (Metoprolol, Propranolol with 3 days prior to examination), calcium treatment or other calcium intake drugs should be discontinued. At the same time, patients who have performed a CT or MRI examination with contrast substance (iodate) will not be performing scintigraphy for a minimum of 3 months. If the patient does not meet these minimum requirements, the investigation will be irrelevant.

False positive results are found in the case of: thyroid nodules and carcinomas, thymomas, adenopathies or sarcoidosis (11,14,18,21). False negative results are recorded in small parathyroid adenomas or in those with thyroid hyperplasia $(11,14,18)$. It should be noted that glandular hyperplasia in sHPT is not uniform, most commonly glands of different sizes coexisting in the same patient and, at the same time, that hyperplasia cell populations are present in different proportions (clear cells and oxintic cells). Cases with clear cells predominate can cause false negative results (24). Although the sensitivity of the scintigraphy is high in the adenomas of primary hyperparathyroidism, it decreases in the multiglandular impairment of sHTP due to the lower capture of the radiotracer and its faster elimination (11,19-21,24,25).

Given the lower sensitivity of scintigraphy in sHTP, there are opinions that do not necessarily recommend the preoperative use of this investigation (26). The sensitivity of the scintigraphy is inversely proportional to the number of pathological parathyroids. A "review" dedicated to primary hyperparathyroidism places the sensitivity of scintigraphy at $62-90 \%$ for single adenomas and at only $15-59 \%$ in multiglandular disease (27). In the pluriglandular lesions, the scintigraphy reveals the gland with the largest volume, the other parathyroids being "discreetly" identified (28). Another study comparing the scintigraphic examinations of 40 patients with primary adenomas with 40 cases with sHTP and tertiary hyperparathyroidism, presents distinct results for the two groups of patients. In cases with primary adenomas, the scintigraphy revealed pathological parathyroid in $88 \%$ of patients, whereas in those with sHTP only in $28 \%$ of cases all hyperplastic glands were identified (29). Regarding the patients who underwent surgery for sHTP and have recurrence of the disease, thus requiring surgical reintervention, the scintigraphic examination is indicated in order to locate the remaining or ectopic or supernumerary gland (26).

\section{Other Imaging Methods}

Given the limitations of scintigraphy, these can be improved by its association with SPECT / CT (photon emission emission photography) examinations. Several opinions consider that this combined examination, functional and anatomical, is able to increase the sensitivity of scintigraphy $(30,31)$. The examination reveals better the ectopic parathyroid glands (29). It uses a mobile gamma camera that by rotating around the patient acquires images from different angles. These images are reconstructed computerized and 3D rendered. SPECT is performed in the continuation of the scintigraphy without any 
additional preparation. SPECT diminishes the number of false negative or positive results conferred by classical scintigraphy (28). The lack of availability of the equipment as well as the high costs represent disadvantages of the method. Although parathyroid pathology is not part of its indications, positron emission tomography (PET) has recently been used in sHPT (28). As in the previous case, the lack of equipment and the high costs did not allow the method to be imposed in current practice. However, the examination could be reserved for cases with recurrence of the disease, when the other imaging examinations failed $(19,24)$.

Last but not least, CT and MRI examinations of the cervical region should be considered, which, although considered as second-line investigations in sHTP, can provide useful information in many cases.

The CT examination is useful in cases where ultrasound or scintigraphy did not reveal the lesions. The sensitivity is increased in highlighting the ectopic glands of mediastinum and it is lower for the glands located in the thyroid lodge $(11,14,19)$. At the same time, the sensitivity of $\mathrm{CT}$ evaluation is lower than that of combined scintigraphic examination and SPECT (28). Although the patients examined have CKD, IV contrast administration is necessary and possible with the consent of the nephrologist. Thus, clearer images are obtained and multilevel reconstructions (coronal and sagittal) can be performed, their quality being directly proportional to the number of axial sections (preferably 1-2 $\mathrm{mm}$ ). The ability of $\mathrm{CT}$ to differentiate neighboring tissues according to density is quite good (32) and increased especially with the occurrence of $4 \mathrm{D}-\mathrm{CT}$. The major disadvantage of $4 \mathrm{D}-\mathrm{CT}$ is the irradiation dose $3-4$ times higher than that of ordinary CT (33). At the same time, respiratory movements or swallowing can influence the outcome of the examination.

The MRI examination has a discreetly increased sensitivity as against the CT examination and it is especially useful in detecting mediastinal parathyroids and can also be performed on operated patients in whom recurrence of the disease occurs $(21,28)$. Of course, compared to the CT exam, it does not present the risk of irradiation but it involves higher costs. In the case of MRI as well, the sensitivity decreases in the pluriglandular involvement of sHPT compared to that of solitary adenomas (42-53\% compared to 50-88\%) (28). However, some authors also indicate high percentages in the case of hyperplasia - $75 \%$ (11).

\section{Discussions}

If in the case of adenomas from primary hyperparathyroidism the imaging examinations are most often able to identify the affected gland, in the pluriglandular involvement of sHPT, in many cases, imaging is not able to highlight all the 4 glands, mainly due to the morphopathological heterogeneity existing in this disease. However, it is advisable to obtain preoperatively as much data as possible on the topography of the parathyroid glands; thus the postoperative risk of disease recurrence will be as low as possible. Although first-line imaging tests in sHPT are represented by cervical region ultrasonography and parathyroid scintigraphy, second-line examinations - CT and MRI - are becoming increasingly important in investigating this condition. Their usefulness is found especially in cases when the former fail and in the mediastinal ectopic parathyroid locations as well.

The intraoperative bilateral cervical exploration and the detection of 4 parathyroid glands is indicated in sHPT. Although most authors recommend in sHPT to perform routine imaging tests prior to the surgical operation, in some cases these tests may be useless, as they cannot detect 4 parathyroid glands.

The authors' opinion is in favor of performing the cervical ultrasonography prior to surgery, the examination having an orientative character and visualizing the thyroid gland with its possible associated lesions. At the same time, as much as possible, we also consider for the preoperative scintigraphic examination, despite its limitations in sHTP. In cases of recurrence of the disease we consider that the ultrasonography should be associated with a more sensitive imaging examination - scintigraphy (Figs. 3 and 4), CT (Fig. 5) or MRI (Fig. 6) (34), the exception being the recurrences after subtotal parathyroidectomy in B. Stanescu manner (Fig. 7) $(10,35,36)$. In this case, at the first surgical intervention, an inferior parathyroid gland was 


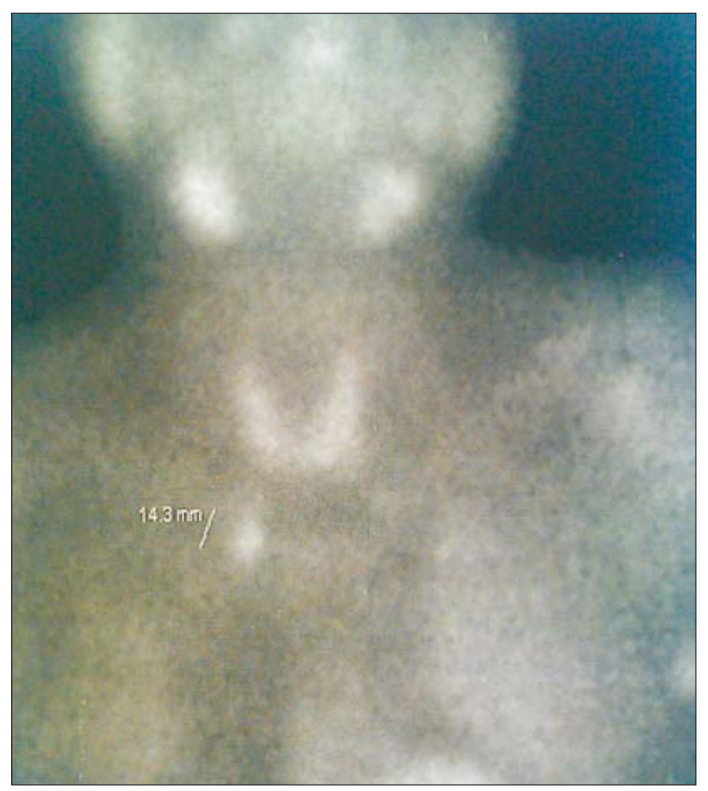

Figure 3. Parathyroid scintigraphy in disease recurrence reveals retrosternal ectopic right inferior gland in mediastinum

(Clinical archive. Retrieved after 34)

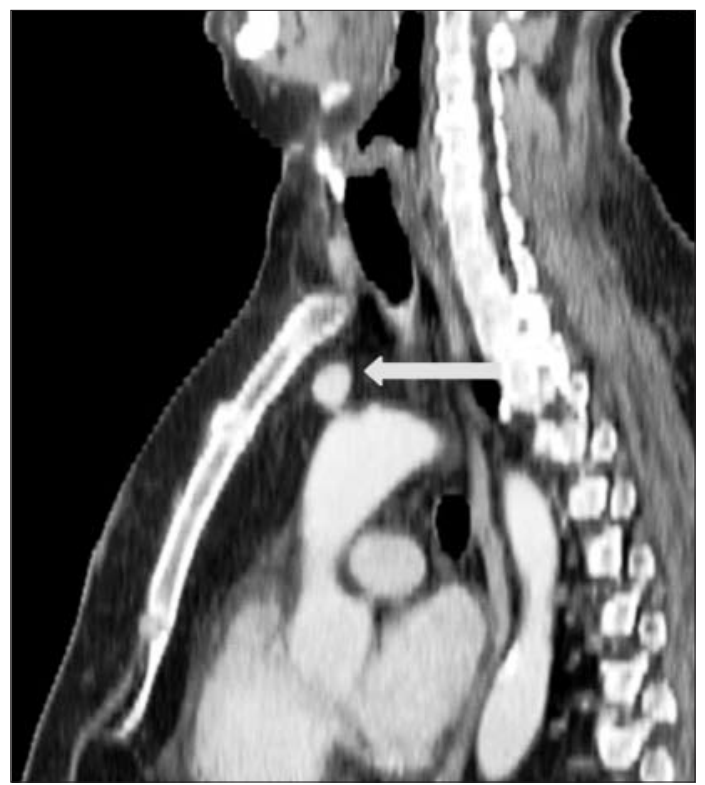

Figure 5. CT with IV contrast: anterior mediastinal ectopic parathyroid in a patient with recurrent hyperparathyroidism

(Clinical archive. Retrieved after 34)

mobilized and placed subcutaneously above the sternal notch, where it was sectioned subtotally. If the recurrence of the disease occurs, the surgical reintervention can be performed under local anesthesia, the remaining glandular

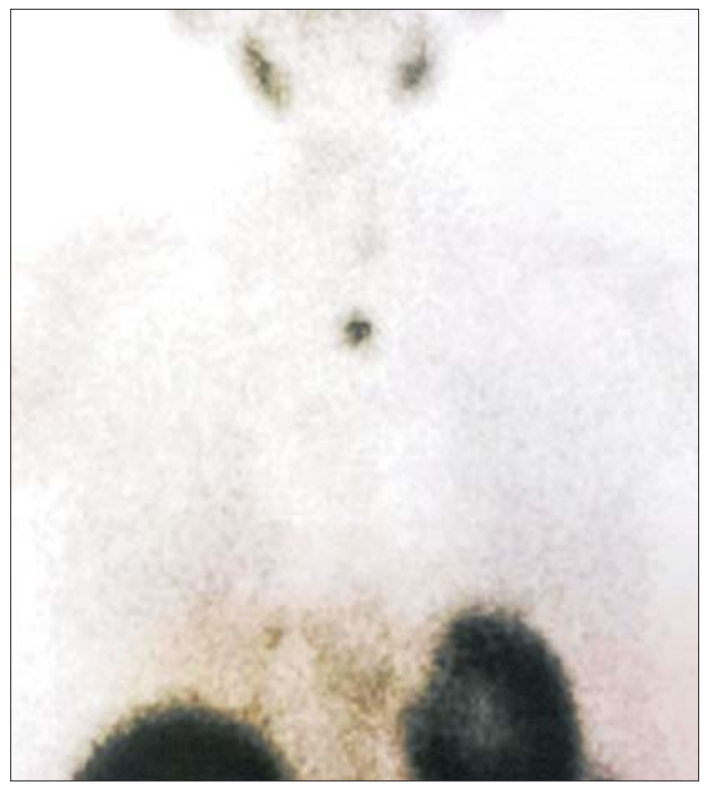

Figure 4. Parathyroid scintigraphy: ectopic left inferior gland in mediastinum (Clinical Archives)

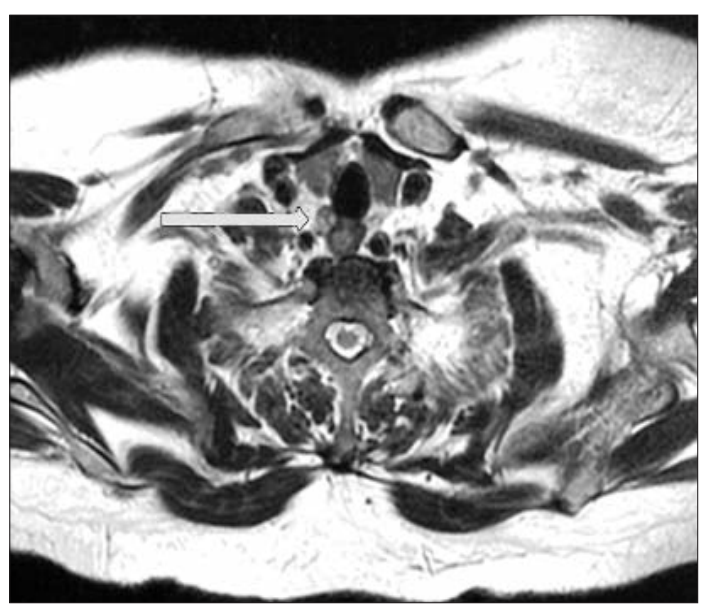

Figure 6. MRI exam: Lower right parathyroid gland in SHTP (Clinical archive. Retrieved after 34)

fragment being superficial and easily accessible.

On several occasions the scintigraphy, properly performed both in our clinic and in other centers with experience, was not able to highlight 4 parathyroid glands, glands that were detected intraoperatively and then confirmed histopathologically. Moreover, in some cases with postoperative recurrence of hyperpatathyroidism, in patients with more than one year after the first surgery and with PTH values above 1,000 pg/ml, the scintigraphy gave false negative results 


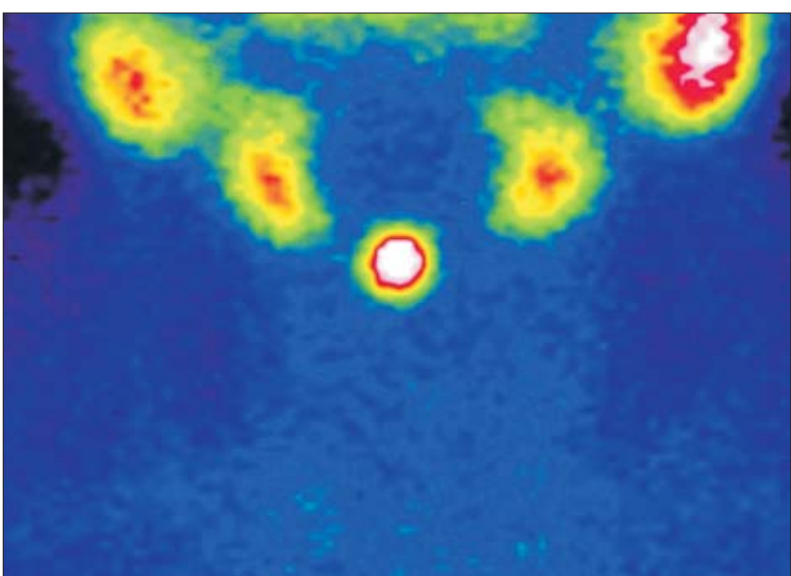

Figure 7. Parathyroid scintigraphy: disease recurrence after subtotal parathyroidectomy in B. Stanescu manner subcutaneous suprasternal glandular remnant. (Clinic archive. Retrieved after 35)

(although theoretically the presence of a single gland should have enabled a good capture up of the radiotracer). These false negative results came from our colleagues in nuclear medicine (with a vast experience in scintigraphy and having new generation equipment available) as well as from other centers with experience in this condition. Therefore, the inability of the scintigraphy to always reveal all the parathyroid glands is a reality.

\section{Conclusions}

The position variants of the parathyroid glands as well as the possibility of supernumerary glands make it necessary to perform preoperative imaging examinations in the case of sHPT. The first line investigations are the ultrasound of the cervical region and parathyroid scintigraphy, which should be performed in all patients.

However, not in few cases, these imaging methods are unable to identify all the parathyroid glands of the patient. The bilateral surgical exploration is the one which has the final word regarding the detection of the glands which were not found by imaging examinations. When this exploration also fails, the intervention is incomplete and the recurrence of the disease is inevitable.

When postoperative recurrence of hyperparathyroidism occurs, the imaging examinations should be resumed. CT or MRI examina- tion may be useful in cases of suspected mediastinal parathyroid ectopy. In patients with recurrence of the disease after subtotal parathyroidectomy in the B. Stanescu manner, the preoperative imaging is not necessary, because the glandular remnant placed subcutaneously suprasternally is much more accessible for surgical reintervention, being outside the thyroid lodge.

\section{Conflict of Interest}

The authors declare no conflicts of interests.

\section{References}

1. Trainor D, Borthwick E, Ferguson A. Perioperative management of the hemodialysis patient. Semin Dial. 2011;24(3):314-26.

2. Gilmour J.R. The gross anatomy of the parathyroid glands. The Journal of Pathology and Bacteriology. 1938;46(1):133-49

3. Wang $C$. The anatomic basis of parathyroid surgery. Ann Surg. 1976;183(3):271-5.

4. Akerström G. Malmaeus J, Bergström R. Surgical anatomy of human parathyroid glands. Surgery 1984;95:14-21.

5. Hooghe L, Kinnaert P, Van Geertruyden J. Surgical anatomy of hyperparathyroidism. Acta Chir Belg 1992;92(1):1-9.

6. McIntyre RC, Eisenach JH, Pearlman NW, Ridgeway CE, Liechty RD. Intrathyroidal parathyroid glands can be a cause of failed cervical exploration for hyperparathyroidism. Am J Surg. 1997; 174(6):750-754

7. Libutti SK, Bartlett DL, Jaskowiak NT, Skarulis M, Marx SJ, Spiegel AM, et al. The role of thyroid resection during reoperation for persistent or recurrent hyperparathyroidism. Surgery. 1997; 122(6):1183-8

8. Shen W, Düren M, Morita E, Higgins C, Duh QY, Siperstein AE, et al. Reoperation for persistent or recurrent primary hyperparathyroidism. Arch Surg. $1996 ; 131(8): 861-869$

9. Butterworth PC, Nicholson ML., Surgical anatomy of the parathyroid glands in secondary hyperparathyroidism. J R Coll Surg Edinb. 1998:43(4):271-3.

10. Bratucu MN, Garofil ND, Radu PA, Paic V, Zurzu M, Goleanu V, et al. Surgical Attitude in Patients with Secondary Hyperparathyroidism Undergoing Dialysis. Chirurgia (Bucur). 2015;110(5):418-24.

11. Cheng D, Jakob LA, Scoutt L. Parathyroid Imaging. In: Oertli D, Udelsman R, editors. Surgery of the Thyroid and Parathyroid Glands. Heidelberg: Springer; 2007. p. 245-259.

12. Randel SB, Gooding GA, Clark OH, Stein RM, Winkler B. Parathyroid variants: US evaluation. Radiology. 1987;165(1):191-4

13. American Institute of Ultrasound in Medicine; American College of Radiology; Society for Pediatric Radiology; Society of Radiologists in Ultrasound. AIUM practice guideline for the performance of a thyroid and parathyroid ultrasound examination. $\mathrm{J}$ Ultrasound Med. 2013;32(7):1319-29

14. Mitchell BK, Merrell RC, Kinder BK. Localization studies in patients with hyperparathyroidism. Surg Clin North Am. 1995;75(3):483-98

15. D Pulgar, A Jara, G González, H González. Tratamiento quirúrgico del hiperparatiroidismo asociado a insuficiencia renal crónica: Experience in 71 patients. Rev. med. Chile. 2015;143:190-96

16. He Q, Zhuang D, Zheng L, Fan Z, Zhou P, Zhu J. Total parathyroidectomy with trace amounts of parathyroid tissue autotransplantation as the treatment of choice for secondary hyperparathyroidism: a single-center experience. BMC Surg. 2014;5;14:26

17. Coakley AJ, Kettle AG, Wells CP, O'Doherty MJ, Collins RE. 99Tcm 
sestamibi--a new agent for parathyroid imaging. Nucl Med Commun. 1989;10(11):791-4.

18. Tunninen V, Varjo P, Schildt J, Ahonen A, Kauppinen T, Lisinen I, Holm A, Eskola H, Seppänen M. Comparison of five parathyroid scintigraphic protocols. Int J Mol Imaging. 2013;2013:921260

19. Henry JF, taieb D, Van Slycke S. Parathyroid Localization and Imaging In: Hubbard J, Inabnet WB, Lo C-Y. Editors. Endocrine Surgery: Principles and Practice. Springer; 2009; p. 235-252.

20. Greenspan BS, Brown ML, Dillehay GL, McBiles M, Sandler MP, Seabold JE, et.al. Procedure guideline for parathyroid scintigraphy. Society of Nuclear Medicine. J Nucl Med. 1998;39(6):1111-4.

21. Greenspan BS, Dillehay G, Intenzo C, Lavely WC, O'Doherty M, Palestro CJ. SNM practice guideline for parathyroid scintigraphy 4.0. J Nucl Med Technol. 2012 Jun;40(2):111-8.

22. The American College of Radiology. ACR-SPR PRACTICE PARAMETER FOR THE PERFORMANCE OF PARATHYROID SCINTIGRAPHY. Online : http://www.acr.org/ /media/ACR/Documents/PGTS/guidelines/Parathy roid_Scintigraphy.pdf

23. Leslie WD, Dupont JO, Bybel B, Riese KT. Parathyroid 99mTCsestamibi scintigraphy: dual-tracer subtraction is superior to double-phase washout. Eur J Nucl Med Mol Imaging. 2002;29(12): 1566-70.

24. Stack BC, Randolph G. Investigations. In: Arora A, Tolley N.S, Tuttle RM , editors. A practical manual of thyroid and parathyroid disease. Singapore : Wiley-Blackwell; 2010. p.164-174

25. Goris ML, Basso LV, Keeling C. Parathyroid imaging. J Nucl Med. 1991;32(5):887-9.

26. Hindié E, Ugur O, Fuster D, O'Doherty M, Grassetto G, Ureña P. 2009 EANM parathyroid guidelines. Eur J Nucl Med Mol Imaging. 2009;36(7):1201-16

27. Ruda JM, Hollenbeak CS, Stack BC Jr (2005) A systematic review of the diagnosis and treatment of primary hyperparathyroidism from 1995 to 2003 Otolaryngol. Head Neck Surg 132(3):359-372

28. Kalinin P., Pavlov AV., Alexandrov YK, Kotova IV, Patrunov NY, Pamputis SN. Assessment of the Scintigraphic Results. In: The Parathyroid Glands Imaging and Surgery. Springer; 2013. p. 24- 28

29. Pham TH, Sterioff $S$, Mullan BP, et al. Sensitivity and utility of parathyroid scintigraphy in patients with primary versus secondary and tertiary hyperparathyroidism. World J Surg. 2006; 30(3): 327-332

30. Lavely WC, Goetze S, Friedman KP, Leal JP, Zhang Z, Garret-Mayer $E$, et al. Comparison of SPECT/CT, SPECT, and planar imaging with single- and dual-phase 99mTc-sestamibi parathyroid scintigraphy. J Nucl Med. $2007 ; 48(7): 1084-9$

31. Wimmer G, Profanter C, Kovacs P, Sieb M, Gabriel M, Putzer D, et al. CT-MIBI-SPECT image fusion predicts multiglandular disease in hyperparathyroidism. Langenbecks Arch Surg. 2010;395(1): 73-80

32. Marmin C, Toledano M, Lemaire S, Boury S, Mordon S, Ernst 0. Computed tomography of the parathyroids: the value of density measurements to distinguish between parathyroid adenomas of the lymph nodes and the thyroid parenchyma. Diagn Interv Imaging. 2012 Jul;93(7-8):597-603

33. Gafton AR, Glastonbury CM, Eastwood JD, Hoang JK. Parathyroid lesions: characterization with dual-phase arterial and venous enhanced CT of the neck. AJNR Am J Neuroradiol. 2012 May;33(5):949-52

34. Victor Strambu. Tablou clinic, biologic si imagistic. In: Chirurgia hiperparatiroidismului secundar. Bucuresti: Ed. Universitara "Carol Davila" 2017

35. Victor Strambu.Complicatii postoperatorii si recurenta hiperparatiroidismului. In: Chirurgia hiperparatiroidismului secundar. Bucuresti: Ed. Universitara "Carol Davila" 2017

36. Badiu C, Stanescu B, Chirurgie endocrina cervicala. Bucuresti: Editura Academiei Române; 2005 